\title{
Research on the Large Steel Cofferdam Floating Scheme
}

\author{
Wang Yusheng \\ School of Navigation, Wuhan University of Technology \\ Hubei Key Laboratory of Inland Shipping Technology \\ Wuhan, P. R. China \\ wangyusheng1990@126.com
}

\begin{abstract}
Steel cofferdam is essential for the construction of the large bridge, which is featured by its huge volume and heavy weight. When steel cofferdam has been built in the shipyard, it would be transit to the bridge construction site by way of waterway. Owing to its no-powered self-propelled, it should be towed through tugboat. Based on the transition of the steel cofferdam for the east Yangtze River Bridge, we propose the floating scheme for the transportation of gigantic steel cofferdam. Our studies are conducting systematically from the floating formation scheme while the navigational environments are taken into account. Within our research, the safe and effective floating transition scheme is devised scientifically. The effectiveness of our steel cofferdam transition scheme is verified by the production instance.
\end{abstract}

Keywords- steel cofferdam; formation; floating scheme; navigation environment; towing

\section{INTRODUCTION}

Steel cofferdam is a major construction component as the structure of cushion caps construction and waterwarding. It is built at the shipyard in general. When construction completed, the steel cofferdam needs floating to the site of the bridge. Limited to some characteristics such as its huge scale and large self-gravity, it should be relied on the tugboat towing navigation. When comes to the floating of the oversized constructional element, without engine the inertia and the length of stroke is large while sailing and berthing, with the stubborn control and not easy to regulate the speed, it is hard to stop it within a very short time and distance in an emergency. The Steel cofferdam has the huge scale and is greatly affected by the wind and flow. Towing navigation and berthing would occupy quite a large water area owing to its huge scale flotilla and the large sailing area [1].

To make sure the steel cofferdam floating smoothly, we study the case of Wangdong Yangtze River Bridge steel cofferdam floating, and do research on the floating plan.

\section{BASIC INFORMATION ABOUT STEEL COFFERDAM FLOATING}

\section{A. Basic information about Wangdong Yangtze River Bridge steel cofferdam floating}

The Wangdong Yangtze River Bridge is located in the northeast of Wangjiang country, spanning the Yangtze at

\author{
Ma Yong ${ }^{*}$ \\ School of Navigation, Wuhan University of Technology \\ Hubei Key Laboratory of Inland Shipping Technology \\ Wuhan, P. R. China \\ myongdl@163.com \\ * Corresponding Author
}

Sijiage and crossing the highway of Jiujiang. The build of steel cofferdam is finished by Jiangxin shipyard in Jiangxi. The maximal length of the steel cofferdam is about $50.4 \mathrm{~m}$, the maximal width is about $26.6 \mathrm{~m}$ (the upper width is $24.5 \mathrm{~m}$, the under width is $26.6 \mathrm{~m}$ ), the maximal height is $28.4 \mathrm{~m}$, and the weight is about $1712 \mathrm{t}$.

The steel cofferdam is floating from the Jiangxin shipyard to the site of the bridge construction. It will be through the water channel of the Hukou, Dongbeiheng, which has huge ship flows and complex traffic surrounding, to arrive at the bridge site.

Within the Balijiang channel, there exist cross water and huge waves when the northeast wind coming. It is the famous gale area of the lower reach. Due to the limited sight and the busy traffic, tugboats should pay more attention to the effect caused by the gale. Especially the towing navigation between Zheji Mountain and the exit of Balijiang, it wills from a complex converging situation if ships pass in and out the exit of Balijiang. So, it should pay attention [2].

The Dongbeiheng water channel has a $105^{\circ}$ bend, so the downbound easily fall bending due to the sweeping bends flow. Steel cofferdam towing fleet should be hung high position, anti sweeping bend water pushing position down to the concave bank, guarantee speed, and prevent the falling curve.

The Dongbeiheng water channel is a fast-flowing river, the steel cofferdam towing fleet was significantly affected by the flow, and the ship's position will be still hanging high after the bend, anti the ship position approaching Pengze crossing mark. Tug should be timely and rudder offsets the amount of flow-induced drift and tries to keep sailing along the center of the channel or deep grooves. So it is important to select an appropriate way for safe of towing operation [3].

\section{B. Basic information about ship towing}

According to different operating environments, requirements and based on the performance characteristics of tugs, the use of tugs can be divided into four kinds hanging drag, push, towing alongside and combined drag.

The main difficulties of towing fleet operation are as follows: the coordination and cooperation with a plurality of tug when navigation or berthing; speed slowly, the position of the ship is difficult to control and it also has a great impact by the wind and the stream; it is easy to produce yaw steering by the wind and flow effect and manipulation, avoid difficulties; the course stability is poor, tow of tug the rudder slowly [4]. If these issues are not 
handled properly, it will intrude on water traffic ways, especially in the restricted waters; even, it will introduce serious towing accidents [5].

\section{FLOATING SCHEME OF THE STEEL COFFERDAM}

\section{A. Information about the scheme}

For this, there are two alternative schemes; one is hanging drag with pushing the second is towing alongside with push. The selection of the steel cofferdam floating is extremely important for the protection of the floating navigation safety during transport, and the following two schemes will be compared and choose the best solution.

Because of the long distance floating, the flow of ships increasing greatly recent years, and have a certain number of crossing water areas, curved and narrow segment, so the navigation environment was complicated [6]. In addition, steel cofferdam towing fleet has a large scale and poor controllability, so when the fleets sailing, turning over and maneuvering for berthing and unberthing will occupy more channel waters, especially in a constricted segment. So the steel cofferdam floating has many security risks [7]. We emphasize on the required width for navigation to pass major segment and the controllability, coordination of the two types of floating scheme, and instance analyses the advantages and disadvantages of the different floating scheme in order to select the optimal scheme.

1) Steel cofferdam floating suggestions scheme A

The undertake unit sends Hgt-1004 and Hgt-2002 take this towage. The Hgt-1004 as the towing tug, Hgt-2002 as the push tug towing the steel cofferdam. The floating formation scheme as showed in Figure 1.

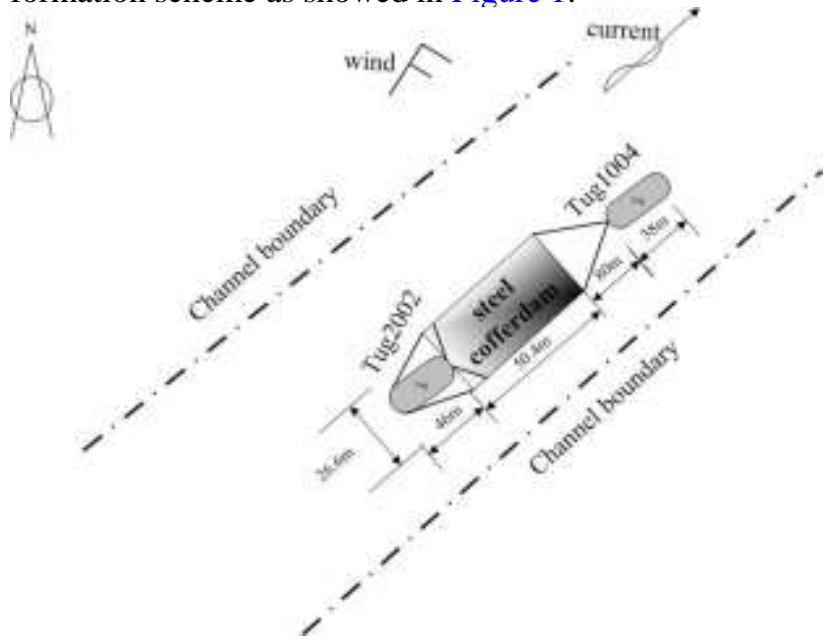

Figure 1. Steel cofferdam floating scheme $A$

Taking into account of wind and current during steel cofferdam float transport, we make Hgt-1004 play a role in hanging drag and provide the power for the steel cofferdam floating; Hgt-2002 push the steel cofferdam in order to control the maneuverability of the steel cofferdam. Floating transport fleet with a total length of about $215 \mathrm{~m}$, the maximum width of about $26.6 \mathrm{~m}$, towing fleet maximum draft of about $2.80 \mathrm{~m}$ and the hanging drag tug have an $80 \mathrm{~m}$ ' distance with steel cofferdam.

This scheme uses two tugs, one pushing and the other one hanging drag, and this is the main working manner of ultra large components that without the power generally suitable for waterway towing. Meanwhile, this method is relatively easy to manipulate, lookout with a nice view, easy to operate, safe and reliable.

2) Steel cofferdam floating suggestions scheme $B$

The Hgt-2002 as the main tug (pushing), the Hgt-1004 as the booster tug (towing alongside, can also be used as emergency tug). Its formation scheme as showed in Figure 2

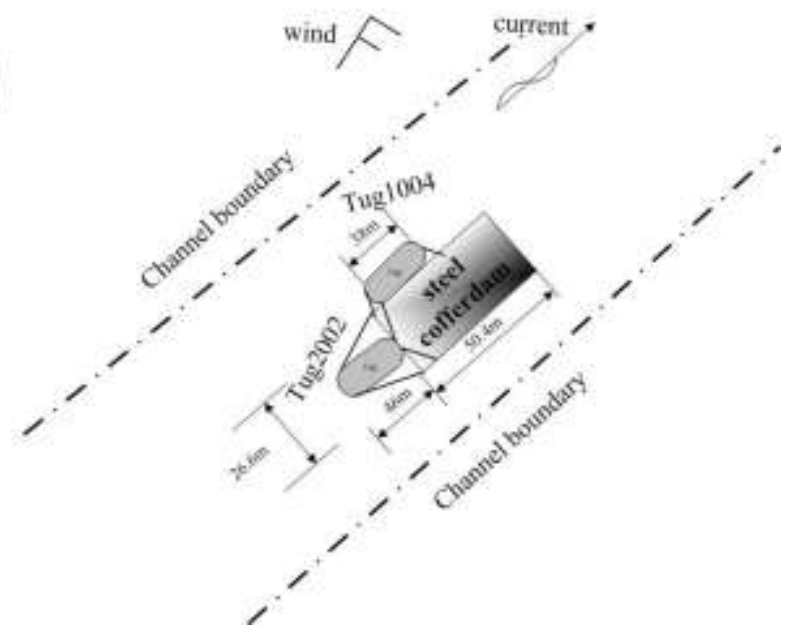

Figure 2. Steel cofferdam floating scheme $B$

This scheme for pushing and towing alongside, firstly, the scale of this scheme is smaller, the occupied width of channel is small too, the effects of wind, current and weather conditions on the towing operations is also small; secondly, the need of width is smaller when passing some curing section of river.

\section{B. Comparison of floating transport fleet operational performance and the emergency disposal}

1) Analysis the operational performance and emergency disposal of scheme A

Ship maneuverability is the ship in accordance with the driver's intentions to maintain or change its speed, course and location of the performance. Fleet's operating performance is good or bad, is not only concerned with handling tugboat itself, but also related to the object amount, size, length and the marshalling formation that towed etc. [8]. One tug pushing and the other one hanging drag are the main working manner of ultra large components that without the power generally suitable for waterway towing. And this method is relatively easy to manipulate, lookout with a nice view, easy to operate, safe and reliable. But the whole towing process affected greatly by weather. The towed steel cofferdam does not have ship structure and with a long tow line so it will be difficult to manipulate under the action of the wind, especially in some special segment. As in pasting Dongbeiheng waterways due to the long length of the towing fleet it will then have a greater yaw and occupy larger waters.

This scheme is greatly affected by weather, and it has a long cable in addition to the towed steel cofferdam without rudder and other ship structure. So if under the action of wind, even with the assistance of the vice tug, it is difficult to control the towed steel cofferdam.

Selected the hanging tug for emergency ship, but there are about $80 \mathrm{~m}$ between the emergency ship with the steel cofferdam so the emergency performance is limited. 
2) Analysis the operational performance and emergency disposal of scheme $B$

First, this scheme has a smaller scale of the floating transport fleet, occupy a smaller channel width, the effects of wind, current and other weather conditions on the towing operations are relatively small. Second, it required a smaller channel width when navigating some bending segment and has a better controllability [9]. Since floating a long distance and the navigation environment is complicated, it is very difficult to control the towed cofferdam relying on the power of the main tug only, especially when sailing to some key corners such as Dongbeiheng waterways. Therefore, in this scheme the main tug plays the role of the main engine of the towed cofferdam, the vice tug plays the role of the rudder of the towed cofferdam. So only through the close cooperation between the main engine and the rudder that can make the towing operation completed successfully [10].

In this way the vision will be limited when lookout, but it would be a lot better to set a lookout platform at the top of the cofferdam. Set the tug that towing alongside as emergency ship. In case of emergency, the tug that towing alongside can be a transient response, has a satisfactory performance of emergency.

\section{The required width for navigation to through key segment}

\section{1) The required width for straight segment}

a) The required width of no wind and current's effect

The need of channel width of steel cofferdam towing fleet can be calculated based on "inland river navigation standard" (GB50139-2004 [11]), and the result as follows:

TABLE I. THE NEED OF CHANNEL WIDTH BY STEEL COFFERDAM TOWING FLEET SAILING FROM JIANGXIN SHIPYARD TO WANGDONG YANGTZE RIVER BRIDGE

\begin{tabular}{|c|c|c|c|c|c|}
\hline Scheme & $L$ & $\boldsymbol{B}$ & $\alpha$ & $\begin{array}{l}\text { One-way } \\
\text { shipping }\end{array}$ & $\begin{array}{l}\text { Two-way } \\
\text { shipping }\end{array}$ \\
\hline \multirow{3}{*}{$A$} & \multirow{3}{*}{$215 \mathrm{~m}$} & \multirow{3}{*}{$26.6 \mathrm{~m}$} & $3^{\circ}$ & $68.13 \mathrm{~m}$ & $105.99 \mathrm{~m}$ \\
\hline & & & $2.5^{\circ}$ & $64.76 \mathrm{~m}$ & $100.73 \mathrm{~m}$ \\
\hline & & & $2^{\circ}$ & $61.39 \mathrm{~m}$ & $95.49 \mathrm{~m}$ \\
\hline \multirow{3}{*}{$B$} & \multirow{3}{*}{$96.4 \mathrm{~m}$} & \multirow{3}{*}{$36.6 \mathrm{~m}$} & $3^{\circ}$ & $74.96 \mathrm{~m}$ & $116.61 \mathrm{~m}$ \\
\hline & & & $2.5^{\circ}$ & $73.45 \mathrm{~m}$ & $114.25 \mathrm{~m}$ \\
\hline & & & $2^{\circ}$ & $71.94 \mathrm{~m}$ & $111.91 \mathrm{~m}$ \\
\hline
\end{tabular}

In the table, $k$ for Correction factor; $L$ for Length of the floating fleet; $B$ for Width of the floating fleet; $\alpha$ for Drift angle; $\beta$ for Angle of current; $\alpha_{f}$ for Wind direction angle; $B_{a}$ for Wind area; $V s$ for Speed of the fleet; $T$ for Answer time of tugboat's rudder; $H$ for Depth of the fleet; $S$ for Calculation of river length, hereinafter the same.

The theoretical calculation shows, the size of the waterway that the steel cofferdam towing fleet passed by can completely satisfy one-way shipping and two-way shipping. In fact, steel cofferdam towing is a one-way operation and the channel width of the waters that the towing fleet passed can meet the needs of its operation demand.

b) The calculation parameter that considered the influence of wind and current
The wind deflection and the role of water will produce drift, when the steel cofferdam was in drag. The calculation parameter that considered the influence of wind and current as described in the following table:

TABLE II. THE CALCULATION PARAMETER OF REQUIRED WIDTH FOR STEEL COFFERDAM TOWING FLEET

\begin{tabular}{|l|c|c|c|c|c|c|c|c|}
\hline Scheme & $\boldsymbol{k}$ & $\boldsymbol{L}$ & $\boldsymbol{B}$ & $\boldsymbol{\alpha}$ & $\boldsymbol{\beta}$ & $\boldsymbol{\alpha}_{f}$ & $\boldsymbol{B}_{\boldsymbol{a}}$ & $\boldsymbol{V}_{\boldsymbol{s}}$ \\
\hline$A$ & $\begin{array}{c}0.04 \\
1\end{array}$ & $\begin{array}{c}21 \\
5 \mathrm{~m}\end{array}$ & $\begin{array}{c}26.6 \\
\mathrm{~m}\end{array}$ & $2^{\circ}$ & $5^{\circ}$ & $90^{\circ}$ & $\begin{array}{l}598.6 \\
7 \mathrm{~m}^{2}\end{array}$ & $\begin{array}{c}8- \\
10 \mathrm{k} \\
\mathrm{m} / \mathrm{h}\end{array}$ \\
\hline$B$ & $\begin{array}{c}0.04 \\
1\end{array}$ & $\begin{array}{c}96 . \\
4 \mathrm{~m}\end{array}$ & $\begin{array}{c}36.6 \\
\mathrm{~m}\end{array}$ & $2^{\circ}$ & $5^{\circ}$ & $90^{\circ}$ & $\begin{array}{l}598.6 \\
7 \mathrm{~m}^{2}\end{array}$ & $\begin{array}{c}8- \\
10 \mathrm{k} \\
\mathrm{m} / \mathrm{h}\end{array}$ \\
\hline
\end{tabular}

2) The required width for curving segment

a) The minimum bending radius

The minimum bending radius of the channel is the main parameters to ensure the safety of the maximum downlink fleet when through the curing segment. The curvature radius of the channel refers to the bend channel's radius of the circle length for the axis. Generally, to avoid aground and collision, the ship should keep caution and slow down when passing through the bend channel.

According to the rule of navigation standard in our country, the minimum bending radius of the channel should be used 3 times the length of the push-train fleets or the length of a cargo ship or 4 times of the maximum length of a single ship from the towing fleet. The minimum bending radius of the channel that the steel cofferdam towing fleet required is shown in Table III.

TABLE III. THE MINIMUM BENDING RADIUS OF THE CHANNEL REQUIRED BY STEEL COFFERDAM TOWING FLEET

\begin{tabular}{|l|c|c|c|}
\hline Scheme & Typical types of vessels & $\boldsymbol{L}$ & $\begin{array}{c}\text { Bend } \\
\text { radius }\end{array}$ \\
\hline$A$ & \multirow{2}{*}{ Steel cofferdam towing fleet } & $215 \mathrm{~m}$ & $860 \mathrm{~m}$ \\
\cline { 3 - 4 } & & $96.4 \mathrm{~m}$ & $385.6 \mathrm{~m}$ \\
\hline
\end{tabular}

The minimum bending radius of curing segment can meet the requirements of safe navigation for the steel cofferdam towing.

\section{b) The width of curved channel}

According to the theory of ship operation, determine the towing fleet required width for navigation without wind action when through bend channel $B_{l}$ wind-induced drift $\Delta B_{F}$ [12]. And based on the theory of superposition principle, we can obtain the channel width which is the typical types of vessels' required by with the influence of wind and current. Parameter selection is shown in Table IV.

TABLE IV. THE MAIN PARAMETER FOR THE CALCULATION OF THE REQUIRED WIDTH IN BENDING CHANNEL

\begin{tabular}{|l|c|c|c|c|c|c|c|c|}
\hline $\begin{array}{c}\text { Sch } \\
\text { eme }\end{array}$ & $\boldsymbol{k}$ & $\boldsymbol{L}$ & $\boldsymbol{B}$ & $\boldsymbol{\alpha}$ & $\boldsymbol{T}$ & $\boldsymbol{V} \boldsymbol{H}$ & $\boldsymbol{H}$ & $\boldsymbol{S}$ \\
\hline$A$ & $\begin{array}{c}0.0 \\
41\end{array}$ & $\begin{array}{c}21 \\
5 \mathrm{~m}\end{array}$ & $\begin{array}{c}26.6 \\
\mathrm{~m}\end{array}$ & $90^{\circ}$ & $20 \mathrm{~s}$ & $8-10 \mathrm{~km} / \mathrm{h}$ & $\begin{array}{l}2.8 \\
\mathrm{~m}\end{array}$ & $\begin{array}{l}4 \\
\mathrm{~L}\end{array}$ \\
\hline$B$ & $\begin{array}{c}0.0 \\
41\end{array}$ & $\begin{array}{c}96 . \\
4 \mathrm{~m}\end{array}$ & $\begin{array}{c}36.6 \\
\mathrm{~m}\end{array}$ & $90^{\circ}$ & $20 \mathrm{~s}$ & $8-10 \mathrm{~km} / \mathrm{h}$ & $\begin{array}{l}2.8 \\
\mathrm{~m}\end{array}$ & $\begin{array}{l}4 \\
\mathrm{~L}\end{array}$ \\
\hline
\end{tabular}

3) The required width for floating fleet to through key segment

In the scheme $A$, the length of the fleet is the sum of the length of steel cofferdam itself with the length of Hgt2002, Hgt-1004 and the distance between steel cofferdam and the hanging drag tug, and the total number is $215 \mathrm{~m}$. 
The width of towing fleet is the width of steel cofferdam and the number are about $26.6 \mathrm{~m}$. In the scheme B, the length of the fleet is the sum the length of steel cofferdam and the length of Hgt-2002, the number is about $96.4 \mathrm{~m}$. The width of towing fleet is the sum of the length of steel cofferdam itself and the width of Hgt-1004, the total number is $36.6 \mathrm{~m}$.

The two schemes have different advantages. Table V gives the comparison result of maximum width at straight segment.

TABLE V. THE NEED FOR MAXIMUM WIDTH OF THE STRAIGHT SEGMENT

\begin{tabular}{|l|c|c|c|c|}
\hline \multirow{2}{*}{$\begin{array}{c}\text { Schem } \\
\mathrm{e}\end{array}$} & \multicolumn{4}{|c|}{ Straight segment } \\
\cline { 2 - 5 } & $\boldsymbol{V} \boldsymbol{s}(\boldsymbol{k m} / \boldsymbol{h})$ & $\begin{array}{c}\text { Flow rate } \\
(\boldsymbol{m} / \mathbf{s})\end{array}$ & Wind scale & Width (m) \\
\hline$A$ & 8 & 3 & 5 & 83.79832 \\
\hline$B$ & 8 & 3 & 5 & 78.9865 \\
\hline
\end{tabular}

In both scenarios, Table VI presents the comparison result of maximum width of curving segment.

TABLE VI. THE NEED FOR MAXIMUM WIDTH OF CURING SEGMENT

\begin{tabular}{|l|c|c|c|c|c|}
\hline \multirow{2}{*}{ Scheme } & \multicolumn{5}{|c|}{ Curing segment } \\
\cline { 2 - 6 } & Waterway & $\begin{array}{c}\text { Vs } \\
(\mathbf{k m} / \mathbf{h})\end{array}$ & $\begin{array}{c}\text { Flow } \\
\text { rate } \\
(\mathbf{m} / \mathbf{s})\end{array}$ & $\begin{array}{c}\text { Wind } \\
\text { scale }\end{array}$ & $\begin{array}{c}\text { Width } \\
(\boldsymbol{m})\end{array}$ \\
\hline$A$ & $\begin{array}{c}\text { Dongbeiheng } \\
\text { waterway }\end{array}$ & 8 & 1 & 5 & 180.4414 \\
\hline$B$ & $\begin{array}{c}\text { Dongbeiheng } \\
\text { waterway }\end{array}$ & 8 & 1 & 5 & 99.41205 \\
\hline
\end{tabular}

\section{COMPARISON BETWEEN TWO SCHEMES}

For pushing and hanging drag scheme, it has a good lookout, suitable for short distance towing, but it greatly affected by weather.

When comes to the scheme $A$, several problems should be highlighted. Firstly, it has difficulties in operation and coordination between push tug and hanging tug has some security risks during navigation. Secondly, when the hanging tug sailing on bending channel, especially with reflux waters, if the tug was sailed into recirculation region by improper operation and with a sudden decrease in speed, it is easy to form a dangerous situation that the tug was being chased by the steel cofferdam [13]. Thirdly, this scheme has a large scale and higher requirements for waterway dimensions. Following that, use this form of towing if has a dangerous situation in the towing process it will be difficult for emergency disposal. Finally, the length of the towing cable is about $80 \mathrm{~m}$ between hanging tug and the steel cofferdam, some vessel may through across the gap and course dangerous situation especially in restricted visibility.

When comes to the scheme $B$, it is almost not influenced by the climatic condition while has a wide application range. Compared with the scheme $A$, this scheme is easier to control the direction of the object towed. Thus, it is sane to adopt this scheme to make the operation more convenient and fast.

TABLE VII. SCHEME COMPARISON OF STEEL COFFERDAM TOWING FLEET

\begin{tabular}{|c|cc|c|}
\hline Parameter & Scheme $A$ & Scheme $\boldsymbol{B}$ \\
\hline Manipulation & The horsepower of & The horsepower of \\
\hline
\end{tabular}

\begin{tabular}{|c|c|c|}
\hline Parameter & Scheme A & Scheme B \\
\hline performance & $\begin{array}{l}\text { tugboat can meet the } \\
\text { requirements, the } \\
\text { streamer of hanging } \\
\text { tugboat is too long, and } \\
\text { the towing fleet has a } \\
\text { length of } 215 \mathrm{~m} \text {, thus } \\
\text { inconvenient } \\
\text { manipulation. }\end{array}$ & $\begin{array}{l}\text { tugboat can meet the } \\
\text { requirements; the length } \\
\text { of the towing fleet is } \\
96.4 \mathrm{~m} \text { and just } \\
\text { moderate, a good } \\
\text { performance of } \\
\text { maneuverability. }\end{array}$ \\
\hline Coordination & $\begin{array}{l}\text { The length of cable } \\
\text { between the steel } \\
\text { cofferdam and the } \\
\text { hanging tug was about } \\
80 \mathrm{~m}, \text { so the } \\
\text { coordination was poor. }\end{array}$ & Better coordination. \\
\hline $\begin{array}{l}\text { Collision } \\
\text { avoidance }\end{array}$ & $\begin{array}{l}\text { The ability of avoidance } \\
\text { was poor, but good at } \\
\text { lookout. }\end{array}$ & $\begin{array}{c}\text { The ability of avoidance } \\
\text { was strong. }\end{array}$ \\
\hline $\begin{array}{l}\text { Emergency } \\
\text { disposal }\end{array}$ & $\begin{array}{l}\text { Hanging tug for } \\
\text { emergency ship, its cable } \\
\text { length with steel } \\
\text { cofferdam was } 80 \mathrm{~m} \text {; the } \\
\text { performance of } \\
\text { emergency is limited. }\end{array}$ & $\begin{array}{l}\text { The tug towing } \\
\text { alongside of emergency } \\
\text { ship, the performance of } \\
\text { emergency was better. }\end{array}$ \\
\hline $\begin{array}{l}\text { Maximum } \\
\text { width } \\
\text { straight } \\
\text { segment }\end{array}$ & $83.79832 \mathrm{~m}$ & $78.9865 \mathrm{~m}$ \\
\hline \multirow{2}{*}{$\begin{array}{l}\text { Maximum } \\
\text { width } \\
\text { curving } \\
\text { segment }\end{array}$} & Dongbeiheng waterway & Dongbeiheng waterway \\
\hline & $180.4414 \mathrm{~m}$ & $99.41205 \mathrm{~m}$ \\
\hline
\end{tabular}

From the Table VII, we can conclude that, the scheme $A$ is superior to scheme $B$ in lookout; but scheme $B$ is superior to $A$ in manipulation performance, coordination, collision avoidance skills, emergency disposal and the need of wide in navigation, etc.

\section{CONCLUSIONS}

To ensure the steel cofferdam floating safely and smoothly, we put forward two kinds of floating schemes. And comparisons research are conducted respectively from the aspects of manipulation performance, emergency disposal, and the need of wide in navigation, etc. In light of the floating scheme and combined with the case of Wangdong Yangtze River Bridge steel cofferdam floating, and then formulate one scientific and rational floating scheme. The results illustrate that, by using the scientific and reasonable floating scheme $B$, it can provide the reliable basis for decision making for the steel cofferdam floating.

\section{ACKNOWLEDGMENT}

This research was financially supported by the National Natural Science Foundation of China (Grant NO.51309186), the Fundamental Research Funds for Central University (Grant NO.WUT:2013-IV-015), and Research fund of Shandong Jiaotong University of China (Grant NO. Z201248).

\section{REFERENCES}

[1] Mei Yingqun. The feasibility demonstration and actual operation of towing for dead ultra large vessel in narrow channel $[\mathrm{J}]$. Marine Technology, 2009 (1): 2-4.

[2] Yadong. Yang, Yong. Ma. Research on vessel transit capacity of cross area channel based on single vacation M/G/1 model [C] // 
The 2nd International Workshop on Intelligent System and Applications (ISA 2010), 1093-1096, Wuhan, 2010.

[3] Yong Ma, M. Zamirian, Yadong Yang, Yanmin Xu, Jing Zhang. Path planning for mobile objects in four-dimension based on particle swarm optimization with penalty function [J]. Mathematical Problems in Engineering, vol. 2013, 1-9, 2013.

[4] Fan Yujun, Wang Koutao. Key Points of Successfully Towing SEVAN 650 [J]. Navigation of China, 2011,34 (2): 63-67.

[5] A. Fitriadhy, H. Yasukawa, T. Yoneda, K. K. Koh, A. Maimun Analysis of an asymmetrical bridle towline model to stabilise towing performance of a towed ship [J]. Jurnal Teknologi (Sciences \& Engineering) 66:2 (2014), 151-156.

[6] Yang Yadong. Navigation risk analysis of shallow and dangerous waterway of the Yangtze River based on gray theory [J]. Journal of WUT (Information\&Management engineering), 2010, Vol 32 No. 4.
[7] Lu Ping. The feasibility demonstration and actual operation of towing for large cylindrical ocean platform [J]. Marine Technology, 2010 (5): 9-11.

[8] Yang Yadong. Research on the handling performance of the large pushing fleet [J]. Transportation Science \&Technology, 2001 (3).

[9] Han Feng. Study on navigation safety of towing drilling platform in the harbor [D]. Dalian: Dalian Maritime University, 2011.

[10] Liu Fengju, Li Yunhai. Research on the safety towing mode of the no host ship [J]. Integrated transport, 2002 (11).

[11] The Ministry of communications of P. R. China. Navigation standard of inland waterway (GB 50139-2004) [S]. China Communications Press, 2004.

[12] A. Fitriadhy, H. Yasukawa, K. K. Koh. Course stability of a ship towing system in wind [J]. Ocean Engineering, 64 (2013)135-145.

[13] Li Changwei. Research on key technologies of no-power vessels towing [D]. Wuhan: Wuhan University Of Technology, 2010. 